\title{
Age-specific anti-mullerian hormone nomogram in Şanlıurfa
}

\author{
Șanlıurfa'da yașa özgù anti-müllerian hormon nomogramı
}

\author{
Adnan KiRMiT ${ }^{1}$, Ahmet Berkiz TURP²
}

\section{ABSTRACT}

Objective: Antimullerian hormone (AMH) levels are generally considered a good predictor of ovarian reserve. Şanlıurfa, is the city with the highest fertility rate in Turkey. The aim of this study is to determine the age spesific serum AMH nomogram of the patients with infertility complaints in Şanlıurfa and its relationship with fertility.

Methods: The records of patients who applied to Harran University Research and Application Hospital infertility outpatient clinic and whose AMH levels were measured were reviewed retrospectively. All patients registered between February 2017 and September 2018 were included in this retrospective study. A total of 3667 patient data were included in the study. Age-specific distribution of AMH levels was determined. Serum AMH levels of patients included in the study were routinely determined in a single laboratory using the ECLIA method in a C601 autoanalyser with the same brand kits, and the results were expressed as $\mathrm{ng} / \mathrm{mL}$. Excessive values (> $30 \mathrm{ng} / \mathrm{mL}$ ) were excluded from evaluation and only the first $\mathrm{AMH}$ value among multiple $\mathrm{AMH}$ measurements was included in the nomogram.

Results: In the histogram analysis, we found that AMH levels showed two peaks at the age of 19 and 23 and

\section{ÖZET}

Amaç: Antimüllerian hormon (AMH) seviyeleri genellikle yumurtalık rezervinin iyi bir öngörücüsü olarak kabul edilmektedir. Şanlıurfa, Türkiye'nin en yüksek doğurganlık oranına sahip ilidir. Bu çalıșmanın amacı Şanlıurfa'daki infertilite şikâyeti olan hastaların serum AMH düzeylerinin yaşa özgü nomogramlarını belirlemek ve doğurganlıkla ilișkisini saptamaktır.

Yöntem: Harran Üniversitesi Araștırma ve Uygulama Hastanesi infertilite polikliniğine müracaat eden ve $\mathrm{AMH}$ düzeyleri ölçülmüş olan hastaların kayıtları retrospektif olarak incelendi. Bu retrospektif çalıșmaya Şubat 2017 ile Eylül 2018 arasında kayıtlı olan tüm hastalar dahil edildi. Çalıșmaya toplam olarak 3667 hasta verisi dâhil edildi. AMH seviyelerinin yașa özgü dağılımı tespit edildi. Çalışmaya dahil edilen hastaların serum AMH düzeyleri, aynı marka kitlere sahip bir C601 otoanalizöründe ECLIA yöntemi kullanılarak tek laboratuvarda rutin olarak saptanmış ve sonuçlar $\mathrm{ng} / \mathrm{mL}$ olarak ifade edildi. Așırı değerler (>30 ng/mL) değerlendirme dişında tutuldu ve birden fazla AMH ölçümlerinden yalnızca ilk AMH değeri nomograma dahil edildi.

Bulgular: Histogram analizinde, AMH düzeylerinin 19 ve 23 yașında iki tepe noktası gösterdiğini ve daha sonra azalan bir eğilim gösterdiğini tespit ettik. Serum AMH

'Harran University, Faculty of Medicine, Department of Biochemistry, Şanlıurfa

${ }^{2}$ Silifke State Hospital, Department of Obstetrics and Gynecology, Mersin

İletişim / Corresponding Author : Adnan KIRMiT

Harran Üni. Hast. Tibbi Biyokimya Lab. Osmanbey Kampüsü, Haliliye 63290 Şanlıurfa - Türkiye Geliş Tarihi / Received : 05.03 .2020

E-posta / E-mail : adnankirmit@yahoo.com Kabul Tarihi / Accepted : 03.06.2020

DOI ID : 10.5505/TurkHijyen.2020.34392

Kirmit A, Turp AB. Age-specific anti-mullerian hormone nomogram in Șanlıurfa.

Turk Hij Den Biyol Derg, 2020; 77(4): 413-420 
then entered a decreasing trend. Serum AMH levels were negatively correlated with age $(r=-0.518, p<0.001)$.

Conclusion: This study presents a review of agespecific AMH reference values detected in the same conditions, based on a great number of women with infertility complaints evaluated in Şanlıurfa. It is clear that, without clinical outcome data, the reference values provided for $\mathrm{AMH}$ cannot be used alone for counseling about a woman's successful ovulation induction or chances of having a child. Whereas, these data may be useful for clinicians to evaluate the ovarian reserve of infertile patients and individualizing the treatment for this, by providing options to evaluate the $\mathrm{AMH}$ value together with regional nomogram, instead of mere the $\mathrm{AMH}$ value.

Key Words: Antimullerian hormone, in vitro fertilization, infertility, ovarian reserve düzeyleri yaș ile negatif korelasyon gösterdi $(r=-0.518$, $\mathrm{p}<0.001$ ).

Sonuç: Bu çalıșma, Șanlıurfa'da değerlendirilen infertilite şikayeti olan çok sayıda kadında, aynı koșullarda saptanan yașa özgü AMH referans değerlerinin incelemesini sunmaktadır. Klinik sonuç verileri olmadan, AMH için sağlanan referans değerlerinin, bir kadının bașarılı yumurtlama indüksiyonu veya çocuk sahibi olma șansı hakkında danıșmanlık için tek bașına kullanılamayacağı açıktır. Bununla birlikte, bu veriler klinisyenlerin infertil hastaların yumurtalık rezervini değerlendirmesinde ve bunun için tedavinin bireyselleștirilmesinde sadece $\mathrm{AMH}$ değeri yerine bölgesel nomogramla birlikte değerlendirmelerine imkân sunarak yararlı olabilir.

Anahtar Kelimeler: Antimüllerian hormon, yardımcı üreme teknikleri, kısırlık, over rezervi

\section{INTRODUCTION}

Şanlıurfa is the city with the highest fertility rate in Turkey (1). It is located in southeastern Turkey, it is based on the pre-existing history of $10.000 \mathrm{BC}$. Being an important city in the Middle East, Şanlıurfa is home to many different ethnic cultures and has the characteristics of representing the Middle East ethnically.

Although the rate of fertility is the highest in Turkey, infertility rate tends to rise here as well as all over the world. In this respect, it has become an attractive subject to investigate the factors affecting fertility and infertility in Şanlıurfa.

Many tests are currently being used in the female factor research of infertility. Of these, age, antral follicle count (AFC) and antimullerian hormone (AMH) levels are generally accepted as the best predictors of ovarian reserve (2). AMH is a common marker of ovarian reserve (3). However, AMH is accepted as the best biochemical test for ovarian reserve (4).

AMH was first discovered in 1947 by Alfred Jost (5). AMH is also called mullerian inhibiting agent, mullerian inhibiting factor and mullerian inhibiting hormone. It is a dimeric glycoprotein hormone belonging to the "transforming growth factor-beta" family (4). In humans, the Antimullerian Hormone is encoded by the $\mathrm{AMH}$ gene located on chromosome 19p13.3 (6), while the AMH receptor is encoded by the AMHR2 gene located on chromosome 12 (7).

Although the AMH assay is frequently used today, there are discrepancies in the literature regarding its direct association with pregnancy or birth rates. In general, AMH levels play an important role in determining the counseling provided for the patient and choice of infertility treatment. 
Currently, many studies have shown the correlation between $\mathrm{AMH}$ and age. However, no data are based on large samples of AMH values with age in Turkey. $\mathrm{AMH}$ may have racial or environmental differences (8). Thus, the external reference values may not apply to Turkey.

The aim of our study was to determine the distribution of $\mathrm{AMH}$ levels, which is the ovarian reserve test, of the patients who applied to the infertility outpatient clinic of the University Hospital in Şanliurfa due to their desire to have a child, and also to partly help determine the correct treatment strategies for the patients in the future.

\section{MATERIAL and METHOD}

\section{Study population}

In this study, records of patients who applied to Harran University Research and Application Hospital Obstetrics Outpatient Clinic with the complaint of child request, diagnosed with infertility and was measured AMH levels were reviewed retrospectively. All patients registered between February 2017 and September 2018 were included in our retrospective study. AMH data in the records were included regardless of the period in which the menstrual cycle occurred. Data of 3667 patients were included in the study. 7 patients' data were excluded because of abnormal results (> $30 \mathrm{ng} / \mathrm{mL}$ ) and among the subsequent $A M H$ measurements only the first $A M H$ value was included in the nomogram. As a result 3660 results were used for calculation. Demographic characteristics of the patients were also examined from the file records.

\section{AMH assay}

All serum AMH levels were measured as routinely in same laboratory using ECLIA (Electrochemiluminescence Immunoassay Analyzer) method on an C601 autoanalyzer (Roche, Rotkreuz,
Switzerland) with same-brand kits and the results are presented as $\mathrm{ng} / \mathrm{mL}$. Within-run $\mathrm{CV}$ for $\mathrm{AMH}$ concentrations ranging between 0.7 and 3.4\%; and the repeatability CV value were $1.2 \%$ for cobas e 601 / MODULAR ANALYTICS E 170 analyzers (9). The limit of detection for AMH was $0.01 \mathrm{ng} / \mathrm{mL}$. AMH values of 125 patients whose results were below this were adjusted to $0.01 \mathrm{ng} / \mathrm{mL}$ for statistical calculation.

\section{Statistical analysis}

Analyzes was performed using SPSS for Windows version 22 (SPSS Inc. Co., Chicago, IL, USA). The normality evaluation of $\mathrm{AMH}$ values was done by Kolmogorov-Smirnov test and it was found that it did not show normal distribution. Spearman's correlation analysis was used to analyze correlation between serum $A M H$ values and age. The linear $R 2$ value was calculated to evaluate the degree of fitting of the curve and log-transformed $\mathrm{AMH}$ values were used to establish the Simple linear regression model.

\section{RESULTS}

TIn our histogram analysis, we found that $\mathrm{AMH}$ levels showed two peaks at the age of 19 and 23 and then entered a decreasing trend (Figure-1). Table-1 summarizes the mean (95\% Confidence Interval), median, minimum, maximum and Interquartile Range (IQR) values of different age groups. Figure 2 illustrates the trend of change of $\mathrm{AMH}$ presented in Table 1.

Table 2 shows the patterns of decrease in $\mathrm{AMH}$ levels according to age groups. Decrease rates of $\mathrm{AMH}$ according to age groups increased with increasing age. However, the increased acceleration in this decline is not easily noticeable, as AMH levels decline with age. The highest decreases were observed in the age groups of $31-35,26-30$ and $21-25$, respectively.

Although the rate of decrease was found to be different for each age group, when all age groups 
were taken together, the correlation between $\mathrm{AMH}$ levels and age was investigated and regression was formulated.

The correlation of serum AMH values with patient ages was negative $(r=-0.518, p<0.001)$. The simple linear regression model was $\log (\mathrm{AMH})=1.698$ $0.052 *$ age $(\mathrm{R} 2=0.249, \mathrm{p}<0.001)$, indicating that approximately $24.9 \%$ of serum AMH concentrations were age-related and that $\mathrm{AMH}$ values would decrease by an average of $5.2 \%$ per year.

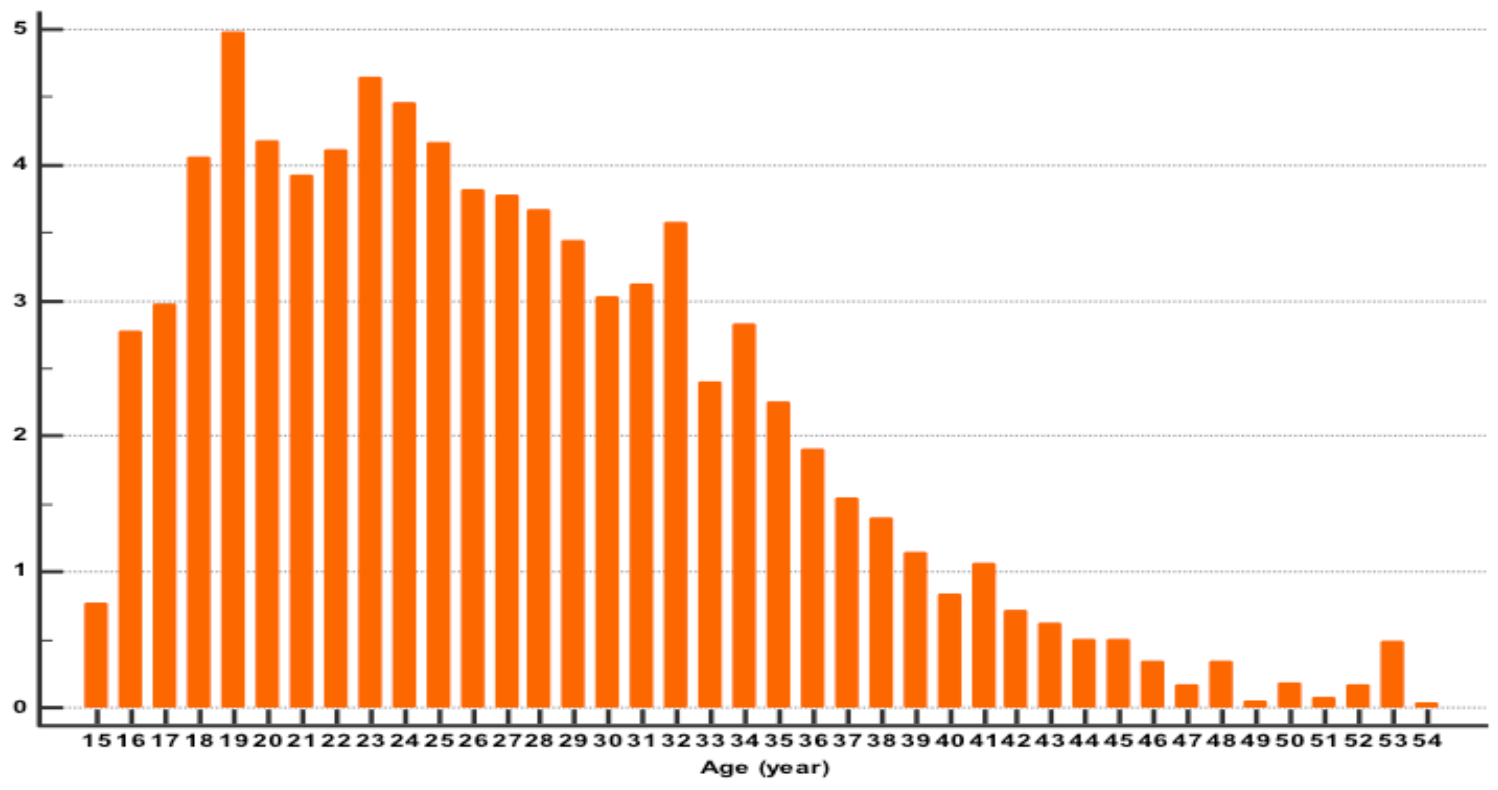

Figure 1. Age spesific AMH levels

Table 1. Distribution of AMH levels $(\mathrm{ng} / \mathrm{mL})$ in different age groups

\begin{tabular}{|c|c|c|c|c|c|c|c|c|c|}
\hline Age Group & $\mathrm{n}$ & Mean & SD & Median & Min & $\operatorname{Max}$ & Q1 & Q3 & IQR \\
\hline$\leq 20$ & 150 & $3,89(3,71-4,87)^{a}$ & 3,6 & 3,38 & 0,01 & 21,08 & 2,05 & 5,92 & 3,86 \\
\hline $21-25$ & 662 & $3,85(3,99-4,58)$ & 3,85 & 3,30 & 0,01 & 29,30 & 1,87 & 5,42 & 3,55 \\
\hline $26-30$ & 893 & $3,16(3,32-3,76)$ & 3,34 & 2,67 & 0,01 & 27,40 & 1,33 & 4,65 & 3,32 \\
\hline $31-35$ & 780 & $2,34(2,60-3,10)$ & 3,54 & 1,72 & 0,01 & 28,60 & 0,73 & 3,68 & 2,94 \\
\hline $36-40$ & 695 & $1,14(1,28-1,58)$ & 2,03 & 0,79 & 0,01 & 22,27 & 0,26 & 1,77 & 1,50 \\
\hline $41-45$ & 375 & $0,52(0,58-0,81)$ & 1,09 & 0,30 & 0,01 & 8,14 & 0,06 & 0,88 & 0,81 \\
\hline$\geq 46$ & 105 & $0,16(0,15-0,31)$ & 0,40 & 0,06 & 0,01 & 2,23 & 0,01 & 0,23 & 0,21 \\
\hline
\end{tabular}

a $\quad: 95 \%$ Confidence Interval

IQR : Interquartile Range 


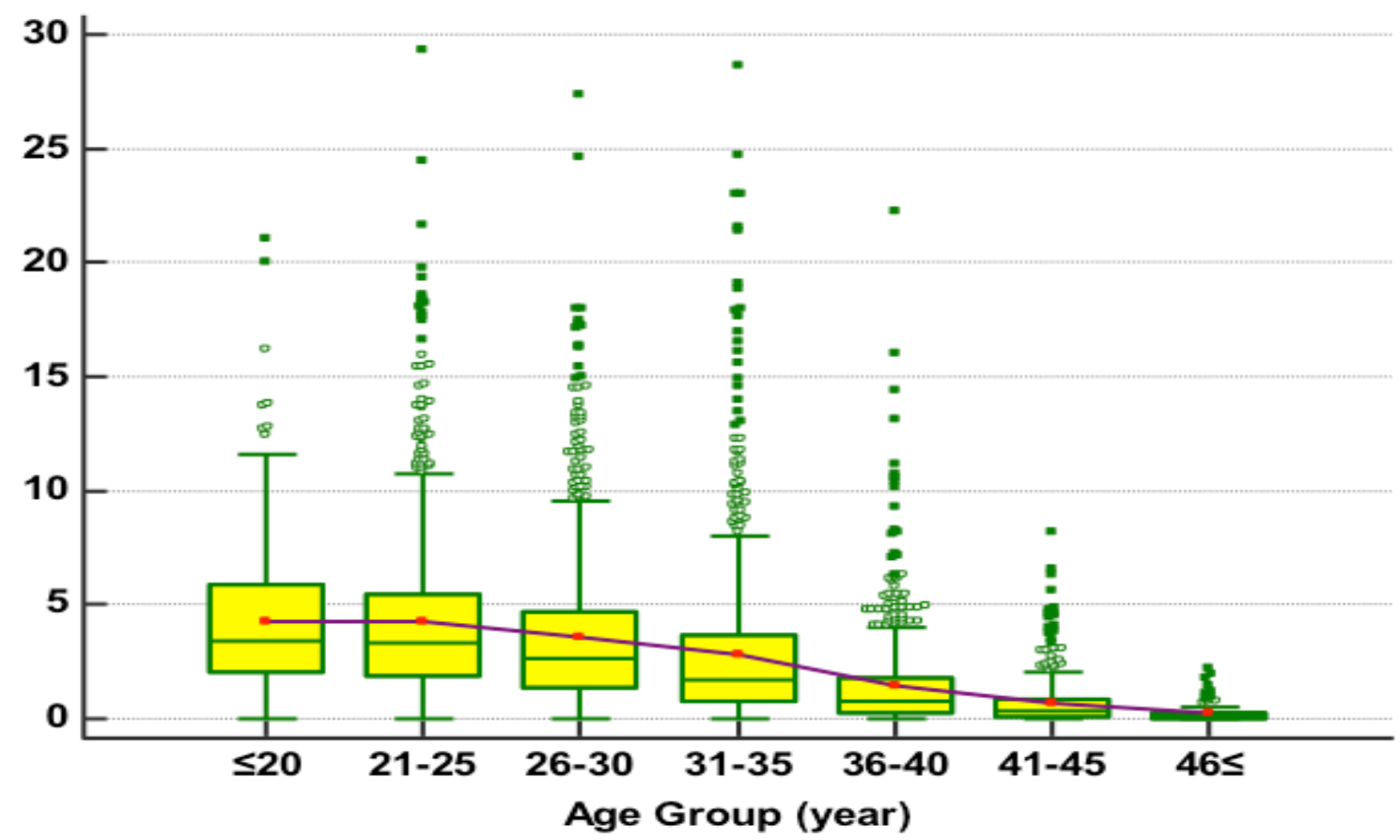

Figure 2. Serum AMH concentrations of different age groups. Values are median (short lines), mean (red point), 25-75th percentiles (boxes) and 95\% confidence interval (whiskers).

Table 2. Declining tendencies of AMH levels according to different age groups

\begin{tabular}{ll|c|c|c|} 
Age Group & $\mathbf{n}$ & Mean $^{\mathrm{a}}$ & AMH Reduction Amount $(\mathrm{ng} / \mathrm{mL})$ & AMH Reduction Ratio (\%) \\
$\leq 20$ & 150 & 3,89 & 0,04 & 1 \\
$21-25$ & 662 & 3,85 & 0,69 & 26 \\
$26-30$ & 893 & 3,16 & 0,82 & 51 \\
$31-35$ & 780 & 2,34 & 1,20 & 54 \\
$36-40$ & 695 & 1,14 & 0,62 & 69 \\
$41-45$ & 375 & 0,52 & 0,36 &
\end{tabular}

a: According to $95 \%$ Confidence Interval 


\section{DISCUSSION}

In our study, serum AMH values was oppositely proportional to rising age, and previous studies confirm this output (10-12). There are similar analysis data concerning AHM which is distributed according to age in both Turkey and the entire world. Scheffer et. al. stated that the $\mathrm{AMH}$ reached its peak level after the 20s and progressively decreased after this age (13). In the study by Zhu et al., the age at which serum AMH levels reached its peak was 24 years (14). In our study, the ages at which AMH reached its peaks was 19 and 23 years old.

The fact that $\mathrm{AMH}$ reaches its peak at the age of 19 , that the decline is stable after 23 years of age and that the ovarian reserve decreases excessively after the age of 31-35 seems to explain the biological reason for the observational early child demand of the people in Şanlıurfa region. Akira Iwase recent review showed also that $\mathrm{AMH}$ is the most reliable marker of ovarian reserve in a wide group of clinical settings however poor for predicting menopause age for rAMH trajectories of time to menopause and the usability of $\mathrm{AMH}$ in the assessment of current fertility is limited and dependent on age (15). See Ling Loy et. al. study similiar results with Chinese women however their study population different from ours. Our study age starts detecting AMH values from age 16 compared to their starting age 26 which made it possible to detect an earlier decline of $\mathrm{AMH}$ value at an early age (16).

Such nomograms may have different local results, as we have done and we have seen in other study results. Such original studies are likely to benefit from the following: When examining a patient with such nomograms to be extracted in the future, it may be more logical to evaluate the patient's own age range in her own region rather than merely assessing the outcome of $\mathrm{AMH}$ as an indicator of ovarian reserve.

In this context, Barad et al. (10) demonstrated that in women reaching IVF (In Vitro Fertilization), age-specific AMH predicts low oocyte yield when it is below the 25th percentile and higher oocyte yield if it is above the age-specific 75th percentile. Our study was retrospective and no anral follicle count was performed. However, these local nomograms can help clinicians choose the right treatment strategies at the right time, taking into account local differences. These local nomograms can help clinicians choose the right treatment strategies at the right time, taking into account local differences.

As a result, when considering the $\mathrm{AMH}$ value, the patient can be provided with better information and counseling compared to the average value generated by the data pool. If local differences are too small to be taken into account, perhaps in the future more accurate $\mathrm{AMH}$ reference ranges can be identified by combining all these data.

Although $\mathrm{AMH}$ is a very good ovarian reserve marker, it is seen that some issues remain inadequate in explaining infertility. One of them, AMH does not have a full predictive value in terms of pregnancy and delivery (17). So it is not a marker that guarantees pregnancy or birth.

High $\mathrm{AMH}$ values can only stimulate the clinician to be careful and take the necessary precautions. By gathering such data in different parts of the world in a common pool, it can be hoped that these data will contribute to a more accurate clinical prediction. It is important to include such nomograms in the literature.

Although the AMH assay is frequently used today, there are discrepancies in the literature regarding its direct association with pregnancy or birth rates (15, 16). In general, $\mathrm{AMH}$ levels play an important role in determining the counseling and choice of infertility treatment.

We hope that with such published studies, regional $\mathrm{AMH}$ nomograms can be used to increase the pregnancy rate and success rate in infertility treatments by providing more accurate counseling to patients. One of the missing points of our study is that 
the AMH blood levels, which are ovarian reserve, do not include all women in Şanlıurfa region. The results here belong only to the patient population. Since $A M H$ is still an expensive test, it is not used as a screening test in the world. In the future, as the test price decreases and accessibility increases, larger data can be obtained. Nevertheless, the data included in our study reflects the general population to a large extent because it is as high as 3600 . The real weakness of this study that we do not know the patients pregnancy rates. This study consists of ovarian reserve data of patients only. Future studies may designed as ovarian reserves corelated with pregnancy rates. This study can open a horizon also for future studies. We know that $\mathrm{AMH}$ is not a scanning test of ovarian reserve because of it is high costs, hence this study can open a horizon also for future studies.

\section{CONCLUSION}

This study provides a review of age-specific $A M H$ reference values detected in the same conditions, based on a great number of women with infertility complaints evaluated in Şanlıurfa. In similar studies around the world, the presence of peaks at the age of 23-24 for serum AMH value was expressed, whereas two peaks (19 and 23 years) were detected at an earlier ages in this study may be related to the high fertility rate in Sanliurfa. Whereas, these data may be useful for clinicians to evaluate the ovarian reserve of infertile patients and individualizing the treatment for this, by providing options to evaluate the $\mathrm{AMH}$ value together with regional nomogram, instead of mere the $\mathrm{AMH}$ value.

\section{REFERENCES}

1. Doğum İstatistikleri, 2016. Ankara: Türkiye İstatistik Kurumu;18.05.2017. Report No: 24647. Available from: http://tuik.gov.tr/PreHaberBultenleri. do?id=24647.

2. Lehmann P, Vélez MP, Saumet J, Lapensée L, Jamal $\mathrm{W}$, Bissonnette $\mathrm{F}$, et al. Anti-Müllerian hormone (AMH): a reliable biomarker of oocyte quality in IVF. J Assist Reprod Genet, 2014;31(4):493-8.

3. Nelson SM, Yates RW, Fleming R. Serum antiMüllerian hormone and FSH: prediction of live birth and extremes of response in stimulated cyclesimplications for individualization of therapy. Hum Reprod, 2007;22(9):2414-21.

4. Demir M. Over Rezerv Tayininde En İyi Belirteç: AntiMülleriyen Hormon (AMH). Türk Klinik Biyokimya Derg, 2013;11(2):79-85.
5. Wilson JD. Sexual differentiation of the gonads and of the reproductive tract. Biology of the neonate, 1989;55(6):322-30.

6. Cate R, Mattaliano R, Hession C, Tizard R, Farber $\mathrm{N}$, Cheung $\mathrm{A}$, et al. Isolation of the bovine and human genes for Müllerian inhibiting substance and expression of the human gene in animal cells. Cell, 1986;45(5):685-98.

7. Imbeaud S, Faure E, Lamarre I, Mattéi M-G, di Clemente N, Tizard R, et al. Insensitivity to antiMüllerian hormone due to a mutation in the human anti-Müllerian hormone receptor. Nature Genetics, 1995;11(4):382-8.

8. Tal R, Seifer DB. Potential mechanisms for racial and ethnic differences in antimullerian hormone and ovarian reserve. Internal J Endocrin, $2013 ; 2013818912$. 
9. Anckaert E, Öktem M, Thies A, Cohen-Bacrie M, Daan NMP, Schiettecatte J, et al. Multicenter analytical performance evaluation of a fully automated antiMüllerian hormone assay and reference interval determination. Clin Biochem, 2016;49(3):260-7.

10. Barad DH, Weghofer A, Gleicher N. Utility of age-specific serum anti-Müllerian hormone concentrations. Reprod Biomed Online, 2011;22(3):284-91.

11. Seifer DB, Baker VL, Leader B. Age-specific serum anti-Müllerian hormone values for 17,120 women presenting to fertility centers within the United States. Fertil Steril, 2011;95(2):747-50.

12. Yoo JH, Kim HO, Cha SW, Park CW, Yang KM, Song 10 , et al. Age specific serum anti-Müllerian hormone levels in 1,298 Korean women with regular menstruation. Clin Exp Reprod Med, 2011;38(2):937.

13. Scheffer JAB, Scheffer B, Scheffer R, Florencio F, Grynberg M, Lozano DM. Are age and anti-Müllerian hormone good predictors of ovarian reserve and response in women undergoing IVF? JBRA Assist Reprod, 2018;22(3):215.
14. Zhu J, Li T, Xing W, Lin H, Ou J. Chronological age vs biological age: a retrospective analysis on agespecific serum anti-Müllerian hormone levels for 3280 females in reproductive center clinic. Gynecol Endocrinol, 20181-5.

15. Iwase A, Osuka S, Goto M, Murase T, Nakamura T, Takikawa S, et al. Clinical application of serum anti-Müllerian hormone as an ovarian reserve marker: A review of recent studies. J Obstetrics Hynaecol Res, 2018;44(6):998-1006.

16. Loy SL, Cheung YB, Fortier MV, Ong CL, Tan HH, Nadarajah $\mathrm{S}$, et al. Age-related nomograms for antral follicle count and anti-Mullerian hormone for subfertile Chinese women in Singapore. PloS one, 2017;12(12).

17. Casadei L, Dominici F, Scaldaferri D, Vicomandi V, Ciacci S, Piccione E. Anti-Müllerian hormone levels and spontaneous pregnancy in women undergoing surgery for benign ovarian cysts. Gynecol Endocrinol, 2018;34(10):909-12. 